\title{
Is the Informalisation of Developing Countries a Solution to Graduate Unemployment? A Gender Based Approach in Cameroon
}

\author{
Etgard Manga Engama \\ ESSEC, University of Douala \\ Cameroon
}

\begin{abstract}
The structuring of the labour market based on the formal/informal duality is becoming a major characteristic of developing countries, especially Cameroon. Demographic pressure leads to an increase in the number of graduates, which contrasts with the decline in the demand for labour in the formal sector and the growth of the informal sector may suggest that this sector is beneficial for graduates. This study shows, in the sight of the insecure nature of jobs and the low wages of the workers, that the informal sector serves only asameans of survival of the individuals who engage into it and that women are victims of wage discrimination in this sector.
\end{abstract}

Keywords: Informalisation, unemployment, certificate, wages, gender

\section{Introduction}

The segmentation of labour markets in developing countries is often characterized by the formal-informal sector dichotomy since the official recognition of the informal sector at the beginning of the seventies. Generally, the dynamics of the analysis of labour markets attributes many precarious characteristics to jobs of the informal sector, unlike the jobs of the formal sector which depend on the primary segment of labour market. The economic declineat the end of the 1980s to which the Bretton Woods institutions intended to find a solution through structural adjustment had many repercussions on the living conditions of households and led to a spectacular increase in the level of poverty. Macroeconomic shocks led to a fall in the level of employment which has as immediate consequences, the growth of the informal sector and an increase in the unemployment rate. At the same time, educational policies aimed mainly at persistently increasing the level of education and number of graduates. Faced with this behaviour of a continuous increase in the number of graduates which can be referred to as "educational Malthusianism" or inflation of certificates, the question of: What is the capacity of the labour market to absorb the ever growing number of graduates? Needs to be addressed. For companies in the private and public sectors, the certificate is the only signal of the potential of its holder although in the course of his career, he can use professional experience and supplementary training.

Statistics relating to the size of the informal sector show this sector is large but its size varies. While Africa has $61 \%$ of urban jobs, Latin America and the Caribbean have $40 \%$ and Asia has a rate between 40 and $60 \%{ }^{1}$. During the 1983-1993 decade, the share of wage earners in the employed labour force in Cameroon fell from 65 to $50 \%$. But in 1992, more than $80 \%$ of the jobs created were in the informal sector which represented only $35 \%$ of jobs in 1983 (Roubaud, 1993). In fact, the Cameroonian government having been compelled to withdraw and being unable to assume its role of main provider of jobs, the small and unstable private sector was unable to employ all the active population. The second employment and informal sector survey (EESI2) carried out in 2010 reveals that the informal sector, with $90,5 \%$ and $90,4 \%$ in 2005 of the employed active population, offers more opportunities of labour market insertion, as against 5,8\% and 3,7\% for the public and formal private sectors respectively ${ }^{2}$. The large size and dominance of the informal sector in terms of absorption of unemployed persons seems to justify why most graduates insert themselves in this sector. The problem of downgrading, and therefore the irreversible decline in the value of certificates arises, given the lowrate of wages in this sector ${ }^{3}$.

\footnotetext{
${ }^{1}$ BECKER, K. F. (2004), "Fact Finding Study: The Informal Economy", Swedish International Development Agency ${ }^{2}$ INS, Enquête sur le secteur informel, Rapport principal, Phase 1, october 2011.

${ }^{3}$ Idem, The rate of employment of the active population in the informal sector at the national level was $20,2 \%$ in 2010 as against $18 \%$ en 2005 .
} 
Studies on the correspondence between certificates and job obtained carried out in France conclude in favour of an increase in the level of education which has beneficial effects not only in terms of the reduction of inequalities between generations, but also a reduction of the risk of unemployment (Maurin, 2007). Three theoretical approaches relating training and job occupied are at the centre of the theory of downgrading: human capital theory, queuing theory or the model of competition for jobs and signalling and discrimination theories. Human capital theory (Becker, 1975) considers that the initial training is an investment likely to increase the productive capacities of an individual and consequently to improve his skills and reward. The labour market and education are therefore in a situation of competition. In the case where the labour market is efficient, firms that aim at maximizing profits should efficiently use the competences of the employees. The competences of the employed individuals should therefore be adapted to the profile of jobs so as to avoid situations of downgrading. However, human capital theory considers the existence of periods during which individuals or the society invests in education beyond needs in educated labour. Such disequilibrium is nevertheless considered to be temporary and is naturally resolved by the reactions of firms (Freeman, 1976). In fact, while the employees are encouraged to invest less in education due to the fall in wages, firms change their productive organisation to benefit from a more qualified labourat a lower cost.

The model of competition for jobs developed by Thurow (1975) considers that productivity and wages depend on the job for which the individuals postulate. In fact, every rationed job constitutes an opportunity of training and the candidates who postulate for it form a queue which has at its head the most educated individuals. Since wages are determined out of the market by administrative procedures, the employer chooses within this queue the candidate with the desired level of productivity. The certificate is thus used as a signal, not of productivity, but employability and adaptability of its holder (Léné, 2002).

Signaling theory (Spence, 1973, 2002) stipulates that the certificate does not increase the productive capacities of individuals since they are innate, but allows a classification according to the competences revealed by the level of education. The basic hypothesis is that there exists a cost of acquiring the signal which decreases with the level of abilities. The selection of competences by certificate enables the allocation of the same jobs to similar individuals and the level of wages set to that of "potential" competences (ability to adapt or to undergo training fora job) or proven abilities. The role of certificate is therefore to discriminate and signal to the employers, the productive capacities of individuals. This justifies the name discrimination theory whose importance lies in the ability of the educational system to optimise the training-employment relationship at minimum cost (Arrow, 1973) through a system of selection prior to employment. Signaling and discrimination theories are perfectly complementary since one is based on the rationality of individual behaviours through signaling and the other on the quest of the optimisation of the benefits of the group by means of signaling.

These three theoretical approaches can complement each other or be alternatives. If the certificate allows the identification of intrinsic abilities acquired in the educational system (Blaug, 1985), this shows a complementarities between the theory of human capital and the theories of signaling and discrimination ${ }^{4}$. However, due to the conception of the labour market, there is an opposition between human capital theory and signaling theory on the one hand, and human capital theory and the theory of competition for jobs on the other. For the first two theories, the wage depends on the characteristics of the individual (supply approach) while for the model of queuing theory, the wage is determined by the characteristics of job (demand approach). According to Adam Smith (1776), the wages paid for different types of jobs have to be in proportion to the financial and non-financial advantages and disadvantages. Thus, workers gain by choosing jobs with higher wages given their talents and competences (Willis and Rosen, 1979; Heckman and Sedlacek, 1985) which are important elements in decision-making to become entrepreneurs (Lazear, 2005; Ñopo and Valenzuela, 2007). Recent studies show that comparative advantage in the labour market is related to the choice of occupation, investment in human capital and the nature of rewards (Carneiro, Heckman and Vytlacil, 2005; Arias and Khamis, 2008). However, within the framework of the Cameroonian economy and especially with regard to the level of unemployment, it is not obvious to talk of choice of occupation. The option of the informal sector seems to be the only alternative for many graduates. Many studies have been carried out in Africa, especially in South Africa. These studies agree on the fact that the informal sector of South Africa which is characterised by its small size, contrasts with the high unemployment rate and differs from those of other African countries for two main reasons.

\footnotetext{
${ }^{4}$ There however exists an opposition between human capital and discrimination theories due to the capacity of the academic institution to increase the individual abilities or reveal the innate abilities and those from the family environment.
} 
On the one hand, it's small size, along with potentially restrictive costs of credit and a high rate of crime against the self-employed (Fields, 2006). On the other hand, a very high reservation wage due to the arbitration by the unemployed between any support and the low and subjective wages of the informal sector (Kingdon and Knight, 2001 and 2007).

This study seeks not only to question the capacity of the informal sector to absorb graduates and reduce unemployment but also to analyse the level of rewards and wage differentials between men and women employed in this sector. This study is organised in 5 sections. Section 2 makes an appraisal of the place of the informal sector in the labour market. Section 3 introduces the methodology of analysis. Section 4 analyses the results of estimates and section 5 presents the conclusion.

\section{An overview of the labour market and the informal sector}

The Cameroonian labour market which survived the economic crisis is made up of a public sector, formerly the main provider of jobs, and a private sector. The latter is divided into the formal private sector -not large enough to absorb unemployment - and an informal private sector - which carries in itself the precarisation of jobs. A large informal sector co-exists with a high unemployment rate, made up of more and more graduates. The concept of informal sector has always been at the center of lively debates between producers of statistics and users the point that it is not possible to give a unique definition (see box 1). However, the operational definition leads us to consider the informal sector to be all production units (goods, trade and/or services) in the private sector that does not have a statistical number or taxpayer's number and/or not having a formala ccounting system in line with the OHADA accounting plan.

\section{Box 1}

The initial model of development economics of A. W. Lewis (1954), « economic development with an unlimited supply of labour» introduces into economic theory the idea according to which wage earners are destined to increase in number with industrialisation and modernisation because of the low productivity of agriculture in rural areas which leads to rural-urban migration. This migration is at the origin of a cheap labour that can start up industrialisation. This model having many limitations, it is criticised by Todaro (1969) and Fields (1975). The size of rural exodus and the demographic growth rate lead to high unemployment rates which push the International Labour Organisation (ILO) to carry out studies in different regions of the world. The famous report of the ILO on Kenya (ILO, 1972) explained how and why the absence of job creation in the modern sector did not lead to an unsustainable increase in unemployment. The concept of the informal sector therefore appears as a major category in the analysis of labour markets in developing countries and explicitly refers to a residual for the first time. In fact, the report shows that rural exodus and urban demographic growth lead to a high unemployment rate, but the development of small businesses enable rural migrants and city dwellers who have been unable to find a job in the modern sector to survive.

The informal sector is thus defined using 7 criteria:

- Easy entry;

- Training acquired out of the school system;

-Non regulated competitive markets

Family ownership of businesses;

- Small scale of operation;

- Use of local resources;

- Adapted technology with high labour intensity.

This concept remains at the center of debates between researchers, particularly on the term «informal sector» which tends to be associated with the formal sector for a structural dualism of developing economies.

Theoretical debates around this concept are based on its definition. The multi-criteria definitions given take into account the type of activity and bring statisticians to adopt criteria (such as the status in the profession, the measurement of self employment, the size of the company, legal status, non registration, level of income and type of accounting) which pave the way for an international definition.

It is not until experts came together during the 15th International Conference of Labour Statisticians (CIST) in 1993 that a definition of the informal sector was arrived at. This definition considers the informal sector as « a set of units producing goods and services in view of mainly creating jobs and income for the people involved. 
These units having a small level of organization, they on a small scale and in a specific manner, with little or no distinction between labour and capital as factors of production. Working relations when they exist are based on occasional employment, parental relationships or personal and social relationships rather than on formal contracts» (BIT, 1993b). From this definition, we can deduce an operational statistical definition that holds whatever the place of work, the nature of buildings, the duration of the activity and its exercise as a main or secondary activity. The informal sector is considered as a set of production units which make up an element in the National Accounting System, in the household institutional sector as sole proprietorships. Sole proprietorships are different from companies because of their legal status and the nature of their accounting: thus, sole proprietorships do not make up independent entities that are seperated from the household that own them and they do not have a complete accounting system that enables to distinguish the production activities of the company and the other activities of the owner.

However, beyond the operationality of the criteria retained in this definition, there is also a concern for coherence with the structural and functional characteristics of the informal sector as regards the ability of the State to ensure the application of the laws and regulations put in place for its development. This definition therefore bears on the most legitimate manner of addressing the nature and specificities of this sector.

Based on the behavioural characteristics of the different actors, we can identify components like microenterprises, (formal entreprises with the number of permanent employees not exceeding 5), independent workers (made up of individuals who are self employed and without a permanent employee) and the self employed (who work for themselves and have help from family members and some occasional salaried workers). The different debates, both current and past, on legality and legitimacy of the informal sector are essentialy centered on the problem of economic and social regulation and its role in the fight against poverty in developing countries. The solutions to these problems that have many negative consequences necessarily pass through the labour market.

The overview of the Cameroonian labour in this study is done on the basis of data coming from a particular survey. Generally, the rate of activity of $69 \%{ }^{5}$ presupposes the inevitable role of the informal sector in the Cameroonian economy.

\subsection{Data used}

A specific survey known as the Second Survey of Employment and the Informal Sector (EESI 2) was carried out by the National Institute of Statistics of Cameroon (INS) in 2010 in order to identify the characteristics of the labour market in general and the informal sector in particular. It was carried out throughout the national territory and is based on a sample of 8160 households, 1323 of which are found in Douala and 1139 in Yaoundé, the economic and political capitals of Cameroon. The stratification of the sample is such as the information of urban and rural areas is recorded in the same capacity as those of the primary, secondary and service sectors, both for the public and private formal and informal companies. This survey reveals the presence of a large informal sector offering job opportunities to men and women. Generally, informal jobs are more occupied by men $71,7 \%$, as against $61,4 \%$ for women.

The salary levels of men and women are shown in table 1. Tableau 1: Monthly salaries of men and women in the public and private (formal and informal) sectors.

\footnotetext{
${ }^{5}$ INS, Enquête sur le secteur informel, Rapport principal, Phase 2, october 2011.
} 


\begin{tabular}{|l|l|l|l|l|}
\hline & Men $(\mathrm{H})$ & Women $(\mathrm{F})$ & {$[(\mathrm{H})-(\mathrm{F})] /(\mathrm{F})$ in \% } & Global \\
\hline Public sector & & & & \\
\hline $\begin{array}{l}\text { Average monthly } \\
\text { salary }\end{array}$ & 141585,2 & 119925,5 & 18,06 & 134995,4 \\
\hline Mediansalary & 131216,3 & 120000 & 9,34 & 128026,6 \\
\hline D1 & 31000 & 30000 & 3,33 & 30000 \\
\hline D9 & 256012,7 & 245839,4 & 4,13 & 253407,4 \\
\hline D9/D1 & 8,15 & 8,19 & - & - \\
\hline Formalprivatesector & & & & \\
\hline Averagemonthlysalary & 115418,6 & 104928,8 & 0,099 & 113469,3 \\
\hline Mediansalary & 65230,02 & 62262,72 & 0,047 & 64958,51 \\
\hline D1 & 26000 & 20000 & 0,300 & 25000 \\
\hline D9 & 252684,2 & 246209,8 & 0,026 & 252464,5 \\
\hline D9/D1 & 9,718 & 12,310 & - & - \\
\hline Informal privatesector & & & & 22359,77 \\
\hline Averagemonthlysalary & 29757,1 & 14954,5 & 0,989 & 12000 \\
\hline Mediansalary & 16734,29 & 8714,20 & 0,920 & 4146,82 \\
\hline D1 & 5933,24 & 3469,546 & 0,710 & 58425,41 \\
\hline D9 & 64176,3 & 33651,07 & 0,907 & - \\
\hline D9/D1 & 10,816 & 9,698 & - & \\
\hline
\end{tabular}

Source: INS, EESI2, 2010, and author's calculations.

Wages appear higher in the public sector relative to the formal private sector which also has the upper hand on the informal sector wages which look miserable. These results show a wage gap in favour of men. This wage gap is almost the same in the whole of the distribution of the formal private sector while it is greater in the informal private sector. We can notice that the inter-professional guaranteed minimum wage (SMIG) does not play its role of floor since in the first percentile of the formal private sector, women have a wage lower than $28216 \mathrm{CFAF}^{6}$ as the men and women of the informal sector. The wages of the formal private sector remain much higher than those of the informal private sector in the whole distribution. From this statistics on the level of wages, we can question ourselves to know if the graduate finds a job that enables him cover the investments in human capital.

\subsection{Distribution of the number of graduates by institutional sector}

The second employment and informal sector survey (EESI 2) shows that despite the high labour force participation rate of $79.1 \%$ for individuals from 15-64 years following the definition of the ILO, the rate of unemployment increases with the level of education as shown in figure 1.

Figure 1 : Rate of unemployment by level of education

\footnotetext{
${ }^{6}$ In fact, Decree $\mathrm{N}^{\circ}$ 2014/2217/PM of the 24 july 2014 increasesthe Minimum Inter-professionnal Guaranteed wagefrom 28.216 FCFA to 36.270 FCFA.

${ }^{7}$ Share of the labour force (Employed and unemployed) in the population from15-64 years 


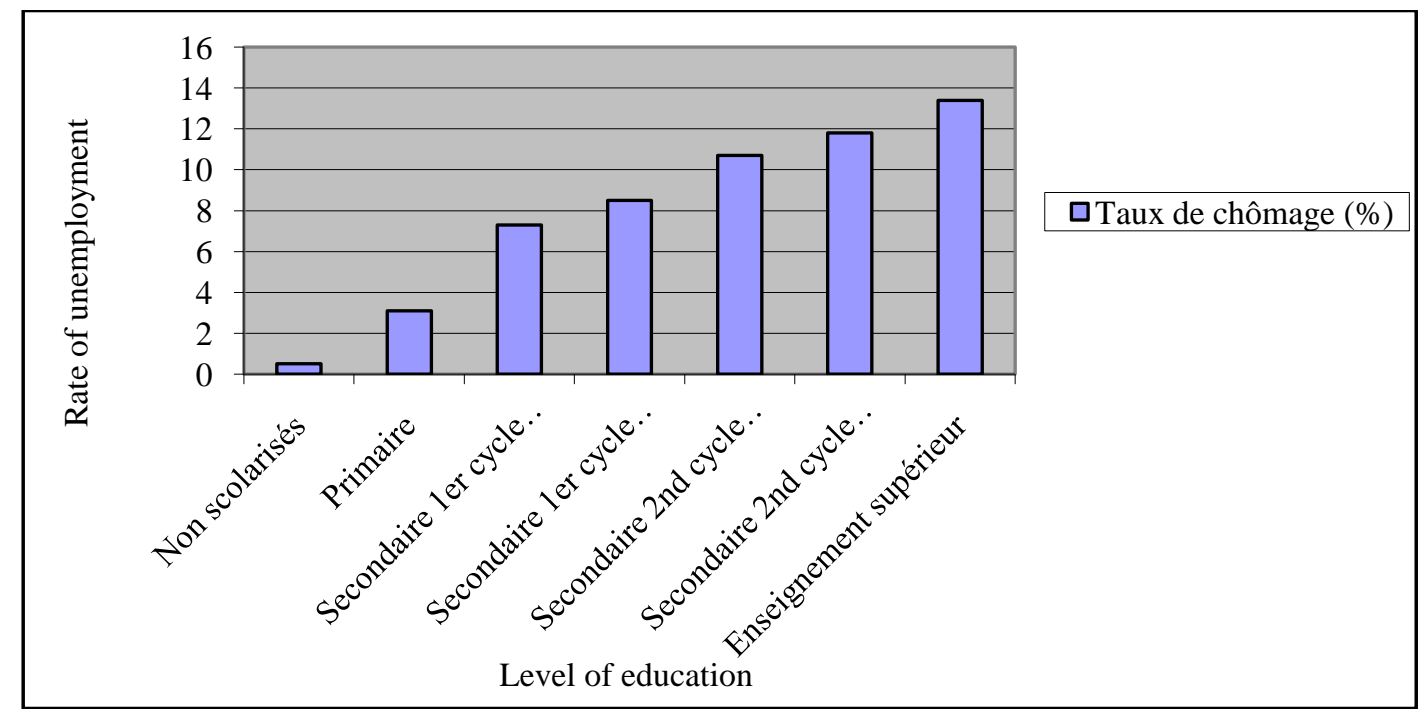

Source : INS, EESI2, 2010, author's calculations.

The unemployment rates shown in this figure are far from showing that the informal sector is capable of employing all individuals who have not been able to insert themselves in the public and formal private sectors. The more certificates an individual has, the lesser his chances of finding a place. These results are reinforced by the fact that at the national level, the unemployment rate is stable at $30 \%$ for the year $2000^{8}$.

A comparative analysis of the number of employed graduates by institutional sector (public, formal private and private informal) shows the dominance of the informal sector. This statistics are in support of the idea according to which in Sub-Saharan Africa, Cameroon is the country with the highest ratio of jobs in the informal sector (Agence Française de Développement, 2006).

The distribution of employees of the public, formal private and informal private sectors is shown in table 2. Table 2 : Distribution of the employees of the public, formal private and informal private sectors by certificate (\%).

\begin{tabular}{|l|l|l|l|}
\hline \multirow{2}{*}{ Certificate } & Institutionalsector & \multicolumn{2}{l|}{} \\
\cline { 2 - 4 } & Public & Formalprivate & Informal private \\
\hline No certificate & 0,93 & 2,48 & 96,58 \\
\hline CEPE/FSLC & 4,25 & 6,73 & 89,02 \\
\hline BEPC/CAP/GCEOL & 15,22 & 16,20 & 68,58 \\
\hline PROBATOIRE & 21,53 & 17,94 & 60,53 \\
\hline BACC/GCEAL/BEPC & 37,82 & 21,67 & 40,51 \\
\hline BTS/DUT/DEUG/HND & 36,05 & 37,41 & 26,53 \\
\hline Bachelors & 47,00 & 25,44 & 27,56 \\
\hline MAITRISE/DEA/MBA & 53,57 & 31,25 & 15,18 \\
\hline DOCTORAT/PHD & 64,29 & 26,19 & 9,52 \\
\hline Total & 9,21 & 8,90 & 81,89 \\
\hline
\end{tabular}

Only graduates who declared their salaries are considered.

Source: INS, EESI2, 2010, author's calculations.

Although all levels of education are represented in the informal sector, it is however necessary to point out that holders of high level certificates of are predominantly in the public sector which unfortunately receives only a small number. The public sector nolonger being the main provider of jobs, this could be a possible explanation of why the unemployment rate grows with the level of education. Globally, the informal sector is the sector that employs many members of the working population, thus showing its predominance. 


\subsection{Predominance of the informal sector and its main characteristics}

The structure of the labour market reveals a large informal sector which enables us to distinguish between the informal agricultural and informal non agricultural sectors. The activities which develop in urban and rural areasare generally primary activities, industry, trade, and services.

Table 3: Structure of employment and sectors of activity by area of residence (\%)

\begin{tabular}{|l|l|l|l|}
\cline { 2 - 4 } \multicolumn{1}{c|}{} & urban & rural & Total \\
\hline Institutional sector & & & \\
\hline Public & 11,99 & 6,07 & 9,39 \\
\hline Formal private & 13,04 & 4,01 & 9,06 \\
\hline Informal private non agricultural & 64,99 & 37,31 & 52,80 \\
\hline Informal private agricultural & 9,98 & 52,60 & 28,75 \\
\hline Total & 100 & 100 & 100 \\
\hline Sector of activity & & & \\
\hline Primary & 10,49 & 53,68 & 29,51 \\
\hline Industry & 20,73 & 15,65 & 18,49 \\
\hline Trade & 22,10 & 10,44 & 16,96 \\
\hline Service & 46,68 & 20,24 & 35,03 \\
\hline Total & 100 & 100 & 100 \\
\hline
\end{tabular}

Only graduates who declared their salaries are considered.

Source : INS, EESI2, 2010, author's calculations.

Table 3 shows that the informal sector is predominant and that its non agricultural activities are more developed in towns, unlike the agricultural activities practiced in rural areas. The same is true for services which, compared tothe primary sector, industry and trade, are predominant and more practiced in towns. A deeper analysis of the distribution of graduates by sector of the informal is given in table 4 .

Table 4: Distribution of workers of the informal sector by sector of activity (\%)

\begin{tabular}{|l|l|l|l|l|l|}
\hline \multirow{2}{*}{ Certificate } & \multicolumn{3}{|l|}{ Sector of activity } & \multirow{2}{*}{ Total } \\
\cline { 2 - 5 } & Primary & Industry & Trade & Service & \\
\hline No certificate & 45,87 & 16,57 & 18,14 & 19,42 & 100,00 \\
\hline CEPE/FSLC & 29,98 & 19,64 & 22,15 & 28,23 & 100,00 \\
\hline BEPC/CAP/GCEOL & 15,25 & 23,52 & 25,18 & 36,05 & 100,00 \\
\hline PROBATOIRE & 11,27 & 24,02 & 21,57 & 43,14 & 100,00 \\
\hline BACC/GCEAL/BEPC & 11,74 & 14,98 & 27,53 & 45,75 & 100,00 \\
\hline BTS/DUT/DEUG/HND & 18,18 & 21,21 & 15,15 & 45,45 & 100,00 \\
\hline Bachelors degree & 8,93 & 7,14 & 25,00 & 58,93 & 100,00 \\
\hline MAITRISE/DEA/MBA & 22,22 & 14,81 & 11,11 & 51,85 & 100,00 \\
\hline DOCTORAT/PHD & 0,00 & 0,00 & 0,00 & 100,00 & 100,00 \\
\hline Total & 32,80 & 18,82 & 21,14 & 27,24 & 100,00 \\
\hline
\end{tabular}

Only graduates who declared their salaries are considered.

Source : INS, EESI2, 2010, author's calculations.

Though it is obvious to note that individuals with no certificate are mainly in the primary sector, it is surprising that all holders of a certificate at least equivalent to BEPC/GCE Ordinary level are mainly in the service sector which is open to holders of all certificates. In terms of employment, the primary sector is the one that employs most active people, possibly because it occupies most individuals with no certificate. However, it receives a considerable number of university graduates. In view of comparing the certificate and the job performed by the individuals, we find that only $3,8 \%$ of employees do a job corresponding to their basic certificate. This statistics reveals that insertion into the informal sector is not related to the level of education. However, 15,22 \% of wage earners undergo a professional training necessary for their job. The employment of graduates in all these sectors would be salutary if given that it is an investment, the individual benefited from a wage proportional to his level of education. 


\section{Econometric approach}

We estimate a wage equation similar to that of Mincer (1974) in which the explanatory variables are the observable characteristics of the individuals (age, seniority, level of education, region, number of children, sector of activity, marital status). The modelis written as follows:

$$
\ln Y_{i}=\beta_{i} X_{i}+\sum_{t=1}^{n} \alpha_{i t} k_{t}+\varepsilon_{i}, \quad t=1,2, \ldots, 8
$$

Where $i$ is the index of the observation; $\ln Y_{i}$ the logarithm of the monthly wage; $X_{i}$ the vector of individual characteristics; $\beta_{i}$ the vector of estimated coefficients; $\alpha_{i t}$ the dummy variables such that, $\alpha_{i t}=1$ if individualiisholder of the certificate (CEPE/FSLC, BEPC/CAP/GCEOL, PROBATOIRE, BACC/GCEAL/BEP, BTS/DUT/DEUG/HND, LICENCE/Bachelors, MAITRISE/DEA/MBA, DOCTORAT/PHD), and $\alpha_{i t}=0$ if not ; $k_{t}$ represents the returns of the certificate $t$; and $\varepsilon$ the error term defined such that $E\left[\varepsilon_{i} \mid X_{0}, \alpha_{i t}\right]=0$ for every individual $i$.

\subsection{Method of estimation}

Given that we have the observed values for the dependent variable (wage) and data on the characteristics of the workers of the informal sector and that our sample is not selected in arandommanner, we should take into account the phenomenon of auto-selection and the risk of selection bias. To this effect, we use the classical two stem method of Heckman (1979). This method has as main feature the estimation of an equation of selection by a probitmodel $^{9}$ which determines a correction term (the inverse of the Mills ratio) which is then included into the equation of wages. Interpreted in the theory of human capital as the unobserved human capital which enables the individual to overcome uncertainty and the requirements of the segment of the labour market in which he works, the opposite of the Mills ratio $\lambda_{i}$ is calculated using the following expression:

$$
\lambda_{i}=\frac{\phi\left(\beta_{i} X_{i}\right)}{\Phi\left(\beta_{i} X_{i}\right)}
$$

Where $\phi$ the normal denstity is function and $\Phi$ is the cumulative normal distribution. The coefficient of the selection bias $\lambda_{i}$ estimates the effect of selection on the wage. Its significance implies that the random allocation of individuals in the informal sector affects the wages obtained and the comparative advantage in their job is at the origin of free occupation. Contrarily, a non significant coefficient is synonymous to a lack of alternatives. Given the difference in wages between men and women which is very visible in the statistics of the sample ${ }^{10}$, our estimates will be done by gender. Thus, in view of explaining this difference of wages between men and women, we carry out a decomposition of wages using the method of Neumark (1988).

\subsection{Decomposition of the gender wage differentials}

The identification of the sources of gender wage differentials is based on the Blinder-Oaxaca (1973) decomposition. Going from a Mincer type wage equation, it consists in writing:

$$
\ln Y^{H}-\ln Y^{F}=\beta^{H}\left(X^{H}-X^{F}\right)+\left(\beta^{H}-\beta^{F}\right) X^{F}
$$

Where $\ln Y^{H}$ and $\ln Y^{F}$ are the logarithms of average wages of men and women respectively; $X^{H}$ and $X^{F}$ are the vectors of the independent variables of men and women; $\beta^{H}$ and $\beta^{F}$ are the estimated coefficients. $\beta^{H}\left(X^{H}-X^{F}\right)$ and $\left(\beta^{H}-\beta^{F}\right) X^{F}$ respectively measure the wage differentials due to differences in characteristics between men and women and the wage differential due to differences in returns from these characteristics. The decomposition of the wage differential can only be operational if the choice of the non discriminatory structure has been rightly made. In other words, what will be the structure of wages without any gender discrimination? Following Neumark (1988), we consider as non discriminatory rule, an estimation of wages on a rewards equation on the whole sample. We thus have a decomposition as follows:

\footnotetext{
${ }^{9}$ The probit model enables the explanation of the probability of being employed.

${ }^{10}$ The activity differential is less remarkable between men and women but is in favour of men and can be explained by a high rate of occupation of women in rural areas
} 


$$
\ln Y^{H}-\ln Y^{F}=\beta^{*}\left(X^{H}-X^{F}\right)+\left[\left(\beta^{H}-\beta^{*}\right) X^{H}+\left(\beta^{*}-\beta^{F}\right) X^{F}\right] .
$$

In this case, the first term measures the wage differentials due to differences in characteristics between men and women; the second and third terms which make up the unexplained difference measures the wage differences between the returns of the whole sample, and those of men and women respectively.

\section{4- Results and analysis}

One of the major consequences of Structural Adjustment Programs (SAPs) was the dis-engagement of the State which led to massive lay-offs, large salary cuts and a large wave of privatisation. Being unable to find jobs in the public and formal private sectors after restrictions on the State budget, different groups of the population, especially young graduates freshly from the educational system were constrained to take jobs in the informal sector. In fact, getting certificates no longer seem to facilitate entry into the labour market given that insertion no longer depends on the level of education or field of study.

Table 5: Estimation of the returns function of the informal sector (using the two step Heckman approach)

\begin{tabular}{|c|c|c|c|}
\hline Variables & Men & Women & Global \\
\hline Constant & $\begin{array}{l}0,254 \\
(0,212)\end{array}$ & $\begin{array}{l}0,221 \\
(0,173)\end{array}$ & $\begin{array}{l}0,367 * * * * \\
(0,137)\end{array}$ \\
\hline Seniority & $\begin{array}{l}0,016^{\text {***** }} \\
(0,002)\end{array}$ & $\begin{array}{l}0,024 * * * * \\
(0,003)\end{array}$ & $\begin{array}{l}0,023^{* * * *} \\
(0,002)\end{array}$ \\
\hline Seniority $^{2}$ & $\begin{array}{l}-0,0002 * * * * \\
(0,00006)\end{array}$ & $\begin{array}{l}-0,0003 * * * * \\
(0,00007)\end{array}$ & $\begin{array}{l}-0,003 * * * * \\
(0,00004)\end{array}$ \\
\hline Age & $\begin{array}{l}0,455^{\text {***** }} \\
(0,033)\end{array}$ & $\begin{array}{l}0,348^{* * * *} \\
(0,037)\end{array}$ & $\begin{array}{l}0,355^{* * * *} \\
(0,025)\end{array}$ \\
\hline Number of workinghours & $\begin{array}{l}0,001^{* * * * *} \\
(0,0001)\end{array}$ & $\begin{array}{l}0,002^{* * * *} \\
(0,0001)\end{array}$ & $\begin{array}{l}0,002 \text { **** } \\
(0,0001)\end{array}$ \\
\hline \multicolumn{4}{|l|}{ Marital status } \\
\hline Single (ref.) & - & - & - \\
\hline Married & $\begin{array}{l}0,257^{* * * * *} \\
(0,027)\end{array}$ & $\begin{array}{l}-0,041 \\
(0,025)\end{array}$ & $\begin{array}{l}0,107^{* * * *} \\
(0,019)\end{array}$ \\
\hline \multicolumn{4}{|l|}{ Number of children } \\
\hline Withoutchildren(ref.) & - & - & - \\
\hline $1-5$ children & $\begin{array}{l}-0,032^{\text {**** }} \\
(0,026)\end{array}$ & $\begin{array}{l}0,034 \\
(0,031)\end{array}$ & $\begin{array}{l}-0,057^{\text {***** }} \\
(0,021)\end{array}$ \\
\hline More than 5 children & $\begin{array}{l}0,056^{\text {***** }} \\
(0,040)\end{array}$ & $\begin{array}{l}0,049 \\
(0,043)\end{array}$ & $\begin{array}{l}-0,029^{* * * * *} \\
(0,030)\end{array}$ \\
\hline \multicolumn{4}{|l|}{ Level of education (Certificat) } \\
\hline Withoutcertificate(ref.) & - & - & - \\
\hline CEPE/FSLC & $\begin{array}{l}0,172 * * * * \\
(0,030)\end{array}$ & $\begin{array}{l}0,190 \\
(0,030)\end{array}$ & $\begin{array}{l}0,247 * * * * \\
(0,022)\end{array}$ \\
\hline BEPC/CAP/GCEOL & $\begin{array}{l}0,310 \\
(0,046)\end{array}$ & $\begin{array}{l}0,389^{* * * *} \\
(0,054)\end{array}$ & $\begin{array}{l}0,448^{* * * * *} \\
(0,035)\end{array}$ \\
\hline PROBATOIRE & $\begin{array}{l}0,467^{* * * * *} \\
(0,079)\end{array}$ & $\begin{array}{l}0,501^{* * * *} \\
(0,106)\end{array}$ & $\begin{array}{l}0,604^{* * * *} \\
(0,064)\end{array}$ \\
\hline BACC/GCEAL/BEPC & $\begin{array}{l}0,480^{\text {***** }} \\
(0,073)\end{array}$ & $\begin{array}{l}0,666^{* * * *} \\
(0,103)\end{array}$ & $\begin{array}{l}0,657^{*} * * * \\
(0,060)\end{array}$ \\
\hline BTS/DUT/DEUG/HND & $\begin{array}{l}0,424 * * * \\
(0,172)\end{array}$ & $\begin{array}{l}0,680^{* * *} \\
(0,315)\end{array}$ & $\begin{array}{l}0,615^{* * * * *} \\
(0,154)\end{array}$ \\
\hline LICENCE/Bachelors & $\begin{array}{l}0,933^{* * * * *} \\
(0,133)\end{array}$ & $\begin{array}{l}1,346 * * * \\
(0,251)\end{array}$ & $\begin{array}{l}1,129^{* * * *} \\
(0,119)\end{array}$ \\
\hline MAITRISE/DEA/MBA & $\begin{array}{l}1,491^{\text {***** }} \\
(0,181)\end{array}$ & $\begin{array}{l}0,924 * * * * \\
(0,414)\end{array}$ & $\begin{array}{l}1,591^{* * * *} \\
(0,170)\end{array}$ \\
\hline DOCTORAT/PHD & $\begin{array}{l}2,107 \text { ***** } \\
(0,599)\end{array}$ & $\begin{array}{l}2,216 \text { *** } \\
(0,287)\end{array}$ & $\begin{array}{l}2,179^{* * * *} \\
(0,494)\end{array}$ \\
\hline \multicolumn{4}{|l|}{ Sector of activity } \\
\hline Primary (ref.) & - & - & - \\
\hline Industry & $\begin{array}{l}0,562 * * * * \\
(0,038)\end{array}$ & $\begin{array}{l}0,337^{* * * *} \\
(0,037)\end{array}$ & $\begin{array}{l}0,383^{\text {***** }} \\
(0,027)\end{array}$ \\
\hline Trade & $\begin{array}{l}0,436^{\text {***** }} \\
(0,039)\end{array}$ & $\begin{array}{l}0,351^{* * * *} \\
(0,040)\end{array}$ & $\begin{array}{l}0,372^{\text {***** }} \\
(0,029)\end{array}$ \\
\hline Service & $\begin{array}{l}0,502^{* * * * *} \\
(0,036)\end{array}$ & $\begin{array}{l}0,577^{* * * *} \\
(0,042) \\
\end{array}$ & $\begin{array}{l}0,559^{\text {***** }} \\
(0,028) \\
\end{array}$ \\
\hline \multicolumn{4}{|l|}{ Region } \\
\hline Far-North (ref.) & - & - & - \\
\hline Adamaoua & $\begin{array}{l}-0,089^{*} \\
(0,052)\end{array}$ & $\begin{array}{l}0,159 * * * * \\
(0,059)\end{array}$ & $\begin{array}{l}0,003 \\
(0,040)\end{array}$ \\
\hline Centre & $\begin{array}{l}0,416^{\text {***** }} \\
(0,056)\end{array}$ & $\begin{array}{l}0,627^{* * * *} \\
(0,056)\end{array}$ & $\begin{array}{l}0,437^{\text {***** }} \\
(0,041)\end{array}$ \\
\hline Yaoundé & $\begin{array}{l}0,402^{* * * * *} \\
(0,053)\end{array}$ & $\begin{array}{l}0,642^{* * * *} \\
(0,061)\end{array}$ & $\begin{array}{l}0,456^{* * * * *} \\
(0,041)\end{array}$ \\
\hline East & $\begin{array}{l}-0,001 \\
(0,055)\end{array}$ & $\begin{array}{l}0,248^{* * * *} \\
(0,061)\end{array}$ & $\begin{array}{l}0,084 * * \\
(0,042)\end{array}$ \\
\hline Littoral & $\begin{array}{l}0,289^{* * * *} \\
(0,059)\end{array}$ & $\begin{array}{l}0,502^{* * * *} \\
(0,059)\end{array}$ & $\begin{array}{l}0,315 \text { **** } \\
(0,043)\end{array}$ \\
\hline Douala & $\begin{array}{l}0,395^{* * * *} \\
(0,049)\end{array}$ & $\begin{array}{l}0,616^{* * * *} \\
(0,055)\end{array}$ & $\begin{array}{l}0,430^{* * * *} \\
(0,038)\end{array}$ \\
\hline North & $\begin{array}{l}0,151^{* * * * *} \\
(0,051)\end{array}$ & $\begin{array}{l}0,142^{* * *} \\
(0,058)\end{array}$ & $\begin{array}{l}0,146^{* * * *} \\
(0,040)\end{array}$ \\
\hline North-west & $\begin{array}{l}-0,472^{* * * * *} \\
(0,058)\end{array}$ & $\begin{array}{l}-0,102^{*} \\
(0,058)\end{array}$ & $\begin{array}{l}-0,360^{* * * * * *} \\
(0,042)\end{array}$ \\
\hline West & $\begin{array}{l}-0,077 \\
(0,052)\end{array}$ & $\begin{array}{l}0,235^{* * * *} \\
(0,055)\end{array}$ & $\begin{array}{l}0,005 \\
(0,039)\end{array}$ \\
\hline South & $\begin{array}{l}0,508^{* * * * *} \\
(0,061)\end{array}$ & $\begin{array}{l}0,683^{* * * *} \\
(0,067)\end{array}$ & $\begin{array}{l}0,533^{* * * * *} \\
(0,047)\end{array}$ \\
\hline South west & $\begin{array}{l}0,374 * * * * * \\
(0,061)\end{array}$ & $\begin{array}{l}0,158^{* * * * *} \\
(0,063)\end{array}$ & $\begin{array}{l}0,316^{\text {***** }} \\
(0,045)\end{array}$ \\
\hline$\lambda$ (inverse of the Mills ratio) & $\begin{array}{l}1,136^{* * * * *} \\
(0,173)\end{array}$ & $\begin{array}{l}0,647 * * * * \\
(0,134)\end{array}$ & $\begin{array}{l}0,803^{* * * *} \\
(0,109)\end{array}$ \\
\hline Number of observations & 5274 & 4792 & 10066 \\
\hline
\end{tabular}


Variable dépendante : logarithme du salaire mensuel

Standard deviations are in brackets. The levels of significance are respectively: $1 \%(* * *), 5 \%(* *)$ et $10 \%(*)$. Source : INS, EESI2, 2010, author's calculations.

Table 5 shows the value of the characteristics of workers of the informal sector terms of rewards. The estimates for men and women are given separately due to the large differences, this is followed by the estimates for the whole sample (Which groups men and women).

Our estimation results show the variables that are significant in the explanation of wages in the informal sector. We for example notice that seniority has a weak but significant effect the rewards of men, women and the whole of the study sample. On the other hand, age contributes largely in the explanation of wages. The signs of the coefficient of seniority and the square of seniority show that wages evolve in a concave manner with seniority i.e. wages increase at a decreasing rate with seniority.

Despite the fact that the informal sector is a segment of the labour market for which no barriers of entry exist, the results shows that the returns vary with the level of education: the higher the level of education of the individual, the greater his reward with the highest reward going to holders of a university certificate. Wages increase with the level of education but the problem lies in the low level of wages in the sector on the one hand, and the insecurity in the sector on the other.

Relative to the activities of the primary sector taken as reference, industry, trade and services have positive and significant coefficients. The service sector has the highest returns and is chosen by most graduates in urban areas. Some regions like the Adamawa, the East, the North-west and West regions have return rates that are not in favour of men while only the North West region, as in the case of the whole sample is not favourable to women. The informal activities carried out more in the political and economic capitals (Yaoundé and Douala) globally yield positive, significant and greater returns. The Mills ratio which is positive and highly significant for men, women and the whole sample shows the necessity to use the method of correction of bias in the estimation of the model. In other words, the non random allocation of individuals to jobs in the informal sector affects the level of wages. The informal sector seems to be the market segment which enables individuals, especially graduates to freely choose their task in a manner that maximizes their expected wages.

In a general manner, the estimated coefficients of the variables of human capital confirm the theoretical expectations on investments in human capital, especially as concerns the rate of returns to education which increases with the certificates and the positive and decreasing effect of seniority. These results show that income in the informal sector depends largely on the human capital characteristics of the individuals. Although there exists no salary scale to regulate the level of wages in this sector, wages, although they are insufficient increase with the level of education. Besides the effect of the observed characteristics on the level of rewards in the informal sector, wage differentials between men and women can be summarised in table 6 .

Table 6: Neumark decomposition of gender differences in wages

\begin{tabular}{|l|l|l|}
\hline & Coefficient & Percentage \\
\hline Decompositon of wage differences & & \\
\hline Explained differences (1) & 0,100 & 17,363 \\
\hline Unexplained differences (2) & 0,479 & 82,636 \\
\hline Male advantages(3) & 0,198 & 34,193 \\
\hline Female disadvantages (4) & 0,218 & 37,632 \\
\hline Interaction between explained and unexplained differences(5) & 0,163 & 28,173 \\
\hline Male/Female wage differences [(1)+(2)=(3)+(4)+(5)] & 0,580 & 100 \\
\hline
\end{tabular}

Source : INS, EESI2, 2010, author's calculations.

The decomposition of returns in the informal sector reveals a large difference in favour of men. This difference is weakly explained by the characteristics of the individuals (17,36\%), showing that the productive characteristics of men and women are not important. The unexplained part of returns which is very large $(82,63 \%)$, is attributed to discrimination. This discrimination is caused by a lower valuation of the female characteristics which also have a high level of disadvantage. Although it is true that women are disadvantaged, the unexplained differences could be due to the nature of the informal sector (mainly insecure activities, lack of career perspectives,...), and the policy of liberalization put in place by public authorities. 


\section{Conclusion}

The fall in labour demand in the modern sector since the end of the eighties, especially in the public administration, leaves an important place to the informal sector in the strategies of households to find a source of livelihood. Demographic growth and an increase in the number of graduates present the informal sector as the only possible way of insertion into the labour market for most graduates. This sector, given the number of people it employs is indispensable in the Cameroonian economy. The analysis of a sample of workers from the second employment and informal sector survey (EESI 2) shows the necessary passage of the majority of individuals (including graduates seeking for a livelihood) through this sector. This survival can be seen through the insecure nature of jobs in the informal sector (absence of written employment contracts with the employer among others), and to the low level of wages paid to the majority of workers. The wages of some workers are not in line with the Minimum Inter-professional Guaranteed Wage (SMIG), which shows an absence of institutional protection. The low level of rewards shows that informal sector jobs do not offer many choices to graduates and only constitutes a means of subsistence. Thus, although it enables some graduates and non graduates to survive, it is far from being a means of fighting general unemployment, especially that of graduates. It is just an alternative to unemployment for most graduates. We find that the rate of unemployment increases with the level of education and this raises concerns on the future of many Cameroonian graduates who are becoming more and more numerous. An analysis of the gender wage differentials in the informal sector reveals the presence of wage discrimination against women. In fact, a large part of the wage differential obtained from the decomposition is not justified by differences in the productive characteristics between men and women.

\section{Références}

Adam Smith, (1776).The Wealth of nations. Reprinted, New York: Modern Library, 1937.

Walther, R.(2006).La formation professionnelle en secteur informel - Rapport sur l'enquête terrain au Cameroun, AFD Document de travail, Mai 2006/17, 45p.

Arias, O. \&Khamis, M. (2008). Comparative Advantage, Segmentation and Informal Earnings: A Marginal Treatment Effects Approach.IZA Discussion Paper, No 3916, 61p.

Arrow, K. (1973). The Theory of discrimination. InAshenfelter, O. et Rees, A. (éds), Discrimination in Labor Markets, Princeton University Press, 3-33.

Blaug, M. (1985). Where are we now in the economics of the education, Economics of Education Review, 4, 1, 17-28.

Becker, G. S. (1975).Human capital: a theoretical and empirical analysis, with special reference to education. $2 \mathrm{M}$ ed., New York, National Bureau of economic Research.

BIT (1993b). Rapport de la Conférence,Rapport pour la XVème Conférence Internationale des Statisticiens du Travail, Genève 19-28 Janvier.

Carneiro, P., Heckman, J. J. \&Vytlacil, J. V. (2005).Evaluating marginal policy changes and the average effect of treatment for individuals at the margin.NBER Working Paper Series 15211, July 2009, 20p.

Fields, G. (1975).Rural-Urban Migration, Urban Unemployment and Unemployment and Job Search Activity in Less Developed Countries.Journal of Development Economics, June.

Fields, G. S.(2006).Labour Market Dualism In The Lewis Model: Reply. Manchester School, University of Manchester, vol. 74(3), 355-359.

Freeman, R. B. (1976).The Overeducated American, New York, NY: Academic Press.

Gherbi, H. (2014).Caractéristiques et déterminants de l'emploi informel féminin en Algérie. Le cas de la wilaya de Bejaia.Mondes en développement 2014/2 ( ${ }^{\circ}$ 166), 45-58

Heckman, J. (1979).Sample Selection Bias as a Specification Error. Econometrica, vol. 47, n 1, 153-161.

Heckman, J. \&Sedlacek G. (1985). Heterogeneity, Agregation and Market Wage Functions: An Empirical Model of Self-Selection in the Labor Market. Journal of political Economy, 93, 1077-1125.

ILO (1972). Employment, Incomes and Equality. A Strategy for Increasing Productive Employment in Kenya, Geneva.

Kingdon, G. \& Knight, J. (2001).Unemployment in South Africa: The Nature of the Beast. WPS/2001.15, Centre for the study of African Economies, Department of Economics, University of Oxford.

Kingdon, G. \& Knight, J. (2007).Unemployment in South Africa, 1995-2003: Causes, Problems and Policies.Journal of African Economies, Oxford University Press, vol. 16(5), 813-843.

Lazear, E. P. (2005). Entrepreneurship. Journal of Labour Economics, 23, 649-680.

Léné, A. (2002).Formation, compétences et adaptabilité. L’alternance en débat. Editions L’Harmattan, Paris. 
Lewis, A. W. (1954). Economic Development with Unlimited Supply of Labour.The Manchester School of Economic and Social Studies, vol. 22, ${ }^{\circ} 2$.

Mincer, J. (1974).Schooling, Experience, and Earnings. New York: National Bureau of Economic Research, Columbia University Press.

Maurin, E. (2007).La nouvelle question scolaire - les bénéfices de la démocratisation.Le Seuil.

Ñopo, H. et Valenzuela, P. (2007).Becoming an entrepreneur.IZA Discussion Paper, $\mathrm{N}^{\circ} 2716$.

Oaxaca, R. \& Ransom, M. (1994).On discrimination and decomposition of wage differentials. Journal of Econometrics, vol. 61, 5-21.

Roubaud, F. (1993).Le marché du travail à Yaoundé 1983-1993. La décennie perdue. Paris, n¹993-09/E, Développement des investigations sur l' ajustement à long terme.

Spence, M. (1973).Job Market Signalling. Quarterly Journal of Economics, vol. 87, 353-374.

Spence, M. (2002).Signalling in Retrospect and the Informational Structure of Markets. American Economic Review, American Economic Association, vol. 92(3), 434-459.

Thurow, L. C. (1975).Generating Inequality. Basic Books, New York.

Todaro, M. (1969).A Model of Labour Migration in Less developed Countries. American Economic Review, 59 (1), 138-148.

Willis, R. J. \& Rosen, S. (1979).Education and Self-Selection. Journal of Political Economy, vol. 87, no. 5, S7-36. 